\title{
Analisis Kinerja Pengelolaan Sampah Kota Palangka Raya
}

\author{
Muhammad Arif Fathuddin Hamdie ${ }^{1)}$, Adi Jaya ${ }^{2)}$, Evi Veronika Elbaar ${ }^{3)}$, \\ Herry Redin ${ }^{2)}$, Ici Piter Kulu ${ }^{2}$, Dehen Erang ${ }^{4)}$ Palangka Raya, Palangka Raya
${ }^{2)}$ Fakultas Pertanian, Universitas Palangka Raya, Palangka Raya
${ }^{3)}$ Program Studi Agribisnis, Fakultas Pertanian, Universitas Palangka Raya, Palangka Raya
4) Fakultas Keguruan dan Ilmu Pendidikan, Universitas Palangka Raya, Palangka Raya \\ 1) Program Studi Pengelolaan Sumberdaya Alam dan Lingkungan, Program Pascasarjana Universitas
}

Email : hataralagi@gmail.com

\begin{abstract}
Abstrak
Kota Palangka Raya dengan penduduk sebanyak 266.000 jiwa, sampah menjadi salah masalah antara lain disebabkan terbatasnya sarana dan prasarana penunjang angkutan sampah. Rata-rata jumlah sampah terangkut oleh Tim Pengangkut Sampah Kota Palangka Raya hanya mencapai 48,94\% dari total sampah yang harus diangkut setiap bulan yang mencapai 27.628,2 $\mathrm{m}^{3}$. Dengan demikian laju produksi sampah masih lebih cepat dari upaya penanggulangannya. Tujuan penelitian ini adalah mempelajari kinerja pengelolaan sampah di Kota Palangka Raya dari Timbulan Sampah, dukungan Pembiayaan, dan Regulasi, serta mempelajari aspek prioritas sebagai penunjang kinerja pengelolaan sampah agar pengelolaan sampah dapat meningkat lalu aspek-aspek yang merupakan penyebab utama dan dapat mempengaruhi terhadap kinerja pengelolaan sampah, serta bagaimana perencanaan dan komitmen pemerintah Kota Palangka Raya terhadap peningkatan kinerja pengelolaan sampah. Metode penelitian yaitu Deskriptif Kuantitatif, analisis data kinerja pengelolaan sampah dan penetapan prioritas dilakukan dengan modification Likert Scale. Jumlah responden sebanyak 30 orang yang merupakan seluruh pengawas pengelolaan sampah di Kecamatan Pahandut dan Jekan Raya yang menjadi lokasi penelitian. Hasil penelitian menunjukan bahwa tanggapan nilai berupa presentase yang dianggap tepat memerlukan penanganan secara prioritas yakni Sarana persampahan $(81 \%)$ sebagai prioritas pertama, dukungan pembiayaan $(70 \%)$ sebagai prioritas kedua, timbulan sampah (69\%) prioritas ketiga, Regulasi $(65 \%)$, dan prasarana persampahan $(53 \%)$. Secara umum kinerja pengelolaan persampahan di Kota Palangka Raya perlu dilakukan peningkatan penanganan terutama pada sarana persampahan karena jumlah timbulan sampah di Kota Palangka Raya belum seimbang dengan kinerja pengelolaan persampahan.
\end{abstract}

Kata Kunci: Kinerja pengelolaan, sarana dan prasarana, pembiayaan, timbulan sampah, regulasi.

\begin{abstract}
In the city of Palangka Raya with a population of 266,000 people, waste is a problem, among others, due to the limited facilities and infrastructure to support waste transportation. The average amount of waste transported by the Palangka Raya City Garbage Transport Team only reached $48.94 \%$ of the total waste that must be transported every month which reached $27,628.2 \mathrm{~m}^{3}$. Thus, the rate of waste production is still faster than efforts to overcome it. The purpose of this research is to study the performance of waste management in Palangka Raya City from the generation of waste, support for financing, and regulation, as well as to study the priority aspects as supporting the performance of waste management so that waste management can improve and the aspects that are the main causes and can affect the management performance of waste, as well as how the planning and commitment of the Palangka Raya City government towards improving the performance of waste management. The research method is quantitative descriptive, analysis of waste management performance data and priority setting is carried out with a Likert Scale modification. The number of respondents as many as 30 people who are all waste management supervisors in Pahandut and Jekan Raya Subdistricts which are the research locations. The results show that the value response in the form of a percentage that is considered appropriate requires priority handling, namely waste facilities $(81 \%)$ as the first priority, financial support $(70 \%)$ as the second priority, waste generation $(69 \%)$ the third priority, regulation $(65 \%)$, and waste infrastructure $(53 \%)$. In general, the performance of solid waste management in the City of Palangka Raya needs to be improved, especially in the waste facilities because the amount of waste generated in the City of Palangka Raya has not been balanced with the performance of waste management.
\end{abstract}

Keywords: Management performance, facilities and infrastructure, financing, waste generation, regulation. 


\section{Pendahuluan}

Permasalahan pengelolaan persampahan menjadi sangat serius di perkotaan akibat kompleksnya permasalahan yang dihadapi dan kepadatan penduduk yang tinggi, sehingga pengelolaan persampahan sering diprioritaskan penanganannya di daerah perkotaan (Moersid, 2004). Pengelolaan sampah menurut UU No. 18 Tahun 2008 tentang Pengelolaan Sampah diartikan sebagai kegiatan yang sistematis, menyeluruh, dan berkesinam-bungan yang meliputi pengurangan dan penanganan sampah. Menurut Nuryani (2003), secara garis besar pengelolaan sampah yang baik apabila dilakukan secara terorganisir dan terintegratif mulai dari hulu hingga hilir termasuk kepada dampak yang mungkin timbul di dalamnya. Sampah yang merupakan bagian sisa aktifitas manusia perlu dikelola dengan baik agar tidak menimbulkan berbagai permasalahan terhadap kehidupan manusia maupun gangguan pada lingkungan seperti pencemaran lingkungan, penyebaran penyakit, menurunnya estetika dan sebagai pembawa penyakit. Meningkatnya jumlah sampah belum diimbangi oleh meningkatnya kesadaran masyarakat untuk mengusahakan lingkungan hidup yang bersih dan sehat.

Kemampuan pemerintah dalam pengelolaan sampah juga belum mencapai hasil yang optimal, terlihat dari adanya dampak yang ditimbulkan dari sampah yang semakin hari semakin menumpuk. Oleh karena itu, jika tidak tertangani dengan baik maka pada masa mendatang sampah akan menjadi masalah serius karena faktor-faktor yang menyebabkan timbulan sampah seperti jumlah penduduk, keadaan sosial ekonomi serta kemajuan teknologi diperkirakan akan mengalami peningkatan yang signifikan (Slamet, 2000).

Pengelolaan sampah dikatakan optimal jika semua aspek dari pengelolaan sampah berjalan seimbang dan saling menunjang. Pengelolaan sampah terdiri dari beberapa aspek, diantaranya aspek institusi, hukum, pembiayaan, teknis dan operasional serta peran serta masyarakat. Semua aspek tersebut terkait erat dan harus dipahami secara jelas agar tujuan dari pengelolaan sampah yaitu tercapainya efisiensi dalam pengelolaan persampahan dapat terwujud.

Kota Palangka Raya sebagai salah satu kota yang sedang berkembang juga tidak lepas dari masalah sampah. Palangka Raya dengan jumlah penduduk sebesar 266.000 jiwa (BPS Kota Palangka Raya, 2019), masalah sampah menjadi salah satu momok yang senantiasa menjadi sorotan. Ditambah lagi dengan masih terbatasnya sarana dan prasarana penunjang khususnya angkutan sampah menyebabkan masalah sampah di kota ini semakin komplek. Berdasarkan data Dinas Lingkungan Hidup Kota Palangka Raya (2019), timbulan sampah di Kota Palangka Raya mencapai rata-rata 920,94 $\mathrm{m}^{3} /$ hari atau sekitar $138.141,50 \mathrm{~kg} / \mathrm{hari}$. Jumlah sampah yang terangkut oleh tim pengangkutan sampah yang ada di Pemerintah Kota Palangka Raya jika dirata-rata jumlah sampah terangkut setiap bulannya adalah sekitar 13.519,92 m3. Jumlah yang terangkut setiap bulannya ini masih belum maksimal, karena baru mencapai 48,94\% dari total sampah yang harus diangkut setiap bulan yang mencapai 27.628,2 m3. Dengan demikian laju produksi sampah masih lebih cepat dari upaya penanggulangannya.

Penanganan sampah yang masih kurang maksimal akan menyebabkan ketidakpuasan bagi masyarakat. Menurut Hartanto (2006), pelayanan pengelolaan sampah termasuk dalam pelayanan publik yang bertujuan untuk melayani masyarakat dalam pengelolaan sampah yang dihasilkan. Dalam pelayanan pengelolaan sampah sangat dibutuhkan kinerja atau performance yang baik seperti dalam hal frekuensi pengangkutan, jumlah personil maupun jumlah peralatan yang tersedia sehingga pengelolaan sampah dapat berjalan efektif dan efisien serta dapat memberikan kepuasan kepada masyarakat sebagai pelanggan.

Terkait dengan rumitnya pengelolaan sampah, menurut Kuncoro (2009), sebaiknya pengelolaan sampah dilakukan secara menyeluruh dan terintegrasi serta didukung oleh semua lapisan masyarakat. Sikap masyarakat yang masih tidak peduli dengan sampah harus diubah, begitu pula dengan komponenkomponen penentu kebijakan dalam hal ini pemerintah, semuanya harus berubah menjadi lebih baik.

Tujuan dari penelitian ini adalah untuk menganalisis pengelolaan sampah di Kota Palangka Raya dari aspek dan kondisi Sarana, prasarana, timbulan sampah, dukungan pembiayaan dan regulasinya, kemudian aspek dan kondisi mana saja yang menjadi prioritas sebagai penunjang kinerja pengelolaan sampah mana saja untuk ditangani agar kinerja pengelolaan sampah dapat meningkat lalu as pek-aspek yang merupakan penyebab utama dan dapat mempengaruhi terhadap kinerja pengelolaan sampah di 
Kota Palangka Raya serta Bagaimana perencanaan, dan komitmen pemerintah Kota Palangka Raya terhadap peningkatan kinerja pengelolaan sampah ditinjau dari aspek-aspek yang diteliti.

\section{Metode Penelitian}

Penelitian ini menggunakan metode Deskriptif Kuantitatif, yang dilakukan pada 2 (dua) Kecamatan di Kota Palangka Raya, yaitu Kecamatan Pahandut dan Kecamatan Jekan Raya yang berdasarkan zonasi Rencana Tata Ruang Wilayah Kota Palangka Raya kedua kecamatan tersebut merupakan kawasan perkotaan dengan kepadatan penduduk yang sangat besar. Penelitian dilaksanakan selama 2 (dua) bulan dari Bulan Januari sampai dengan Februari 2021.

Teknik sampling adalah Nonprobability Sampling, jumlah sampel yang menjadi responden berjumlah 30 orang yang merupakan sampling jenuh dengan jumlah sampel sama dengan jumlah populasi pengawas lapangan pengelolaan sampah pada 30 wilayah pengawasan operasional.

Penilaian kinerja pengelolaan sampah diukur dengan menilai 5 variabel, yaitu: Sarana Persampahan, Prasarana Persampahan, Pendanaan/Pembiayaan, Kubikasi Sampah Terangkut, dan Peraturan/Regulasi. Data primer dikumpulkan melalui observasi lapangan dan melakukan wawancara dengan panduan kuisioner, data sekunder dikumpulkan dengan melalui studi litetratur. Dilakukan Uji validitas dan Reliabilitas terhadap instrument yang digunakan, dengan hasil keseluruh 26 pernyataan dalam kuisioner yang diuji dinyatakan valid dan reliabel.

Data kualitatif dianalisis dengan analisis deskriptif, sedangkan data kuantitatif dianalisis menggunakan modification likert Scale (modifikasi skala Likert) dengan menggunakan 4 (empat) tingkat skor untuk setiap pernyataan sebagai berikut: Skor 4 : Sangat Tepat (ST), Skor 3 : Tepat (T), Skor 2 : Tidak Tepat (TT), dan Skor 1 : Sangat Tidak Tepat (STT).

\section{Hasil Dan Pembahasan}

\section{a. Keadaan Umum}

Volume sampah terangkat di Kota Palangka Raya pada Tahun 2019 mencapai $162.239 \mathrm{~m}^{3}$ dengan rata-rata per bulan $13.520 \mathrm{~m}^{3}, 83,6 \%$ merupakan sampah di TPS dan 16,4\% lainnya sangkrah, Ratarata volume sampai perbulan $13.520 \mathrm{~m}^{3}$ dengan kisaran $12.378-14.08313 .520 \mathrm{~m}^{3}$. Tabel 1 menunjukkan volume sampai yang terangkut dari TPS dan Sangkrah sepanjang Tahun 2019:

Tabel 1. Volume Sampah Terangkut di Kota Palangka Raya Tahun 2019

\begin{tabular}{ccccc}
\hline \multirow{2}{*}{ No } & \multirow{2}{*}{ Bulan } & \multicolumn{3}{c}{ Volume Sampah Terangkut } \\
& & Sampah di TPS & Sangkrah & Total \\
\hline 1 & Januari & 11.476 & 2.414 & 13.890 \\
2 & Februari & 10.351 & 2.027 & 12.378 \\
3 & Maret & 11.481 & 2.257 & 13.738 \\
4 & April & 11.057 & 2.218 & 13.275 \\
5 & Mei & 11.592 & 2.280 & 13.872 \\
6 & Juni & 11.134 & 2.175 & 13.309 \\
7 & Juli & 11.546 & 2.244 & 13.790 \\
8 & Agustus & 11.496 & 2.199 & 13.695 \\
9 & September & 11.124 & 2.131 & 13.255 \\
10 & Oktober & 11.487 & 2.184 & 13.671 \\
11 & November & 11.140 & 2.143 & 13.283 \\
12 & Desember & 11.716 & 2.367 & 14.083 \\
\hline & Total & 135.600 & 26.369 & 162.239 \\
\hline
\end{tabular}

Sumber: Kota Palangka Raya dalam Angka 2020.

Tempat Pembuangan Sampah (TPS) tersebar di 5 Kecamatan di Kota Palangka Raya berjumlah 110 buah dengan, dengan kondisi baik sebanyak 90,9\% kondisi baik, 7,3\% dalam kondisi sedang, serta 
kondisi rusak ringan dan rusak berat masing-masing 0,9\%. Jumlah TPS terbanyak terdapat di Kecamatan Jakan Raya (63,6 \%) dan paling sedikit di Kecamatan Rakumpit (0,9 \%) (Tabel 2).

Tabel 2. Jumlah TPS Berdasarkan Kondisi dan Kecamatan di Kota Palangka Raya Tahun 2019

\begin{tabular}{ccccccc}
\hline \multirow{2}{*}{ No } & \multirow{2}{*}{ Kecamatan } & \multicolumn{5}{c}{ Kondisi } \\
\cline { 3 - 7 } & & Baik & Sedang & Rusak Ringan & Rusak Berat & Jumlah \\
\hline 1 & Pahandut & 22 & 0 & 0 & 0 & 22 \\
2 & Sabangau & 2 & 1 & 0 & 0 & 3 \\
3 & Jekan Raya & 63 & 5 & 1 & 1 & 70 \\
4 & Bukit Batu & 12 & 2 & 0 & 0 & 14 \\
5 & Rakumpit & 1 & 0 & 0 & 0 & 1 \\
\hline & Total & 100 & 8 & 1 & 1 & 110 \\
\hline
\end{tabular}

Sumber: Kota Palangka Raya Dalam Angka Tahun 2020.

Selanjutnya Pemerintah Kota Palangka Raya menyediakan 12 (dua belas) buah Depo Sampah yang tersebar pada wilayah perkotaan, khususnya Kecamatan Pahandut dan Jekan Raya, sebagai berikut:

1. Depo Mini Mantikei di Kecamatan Pahandut.

2. Depo Mini Pasar Datah Manuah di Kecamatan Jekan Raya.

3. Depo Mini Jl. Hasanudin (depan Jalan Mangku Rambang) di Kecamatan Jekan Raya

4. Depo mini jl. Garuda di Kecamatan Jekan Raya.

5. Depo Mini jl. Marina Permai II di Kecamatan Pahandut.

6. Depo Mini Jl. Junjung Buih di Kecamatan Jekan Raya.

7. Depo Besar Panarung di Kecamatan Pahandut

8. Depo Jl. Sumbawa di Kecamatan Pahandut.

9. Depo G. Obos XII di Kecamatan Jekan Raya.

10. Depo Mini Bakung Merang di Kecamatan Pahandut.

11. Depo Mini Jl. Ramin III di Kecamatan Pahandut.

12. Depo Mini Jl. C. Bangas di Kecamatan Jekan Raya.

\section{b. Kinerja Pengelolaan Sampah}

Penilaian kinerja pengelolaan sampah dilakukan dengan menilai 5 (lima) variabel Sarana Persampahan (X1), Prasarana Persampahan (X2), Dukungan Pembiayaan (X3), Timbulan Sampah (X4), dan Regulasi (X5). Hasil rekapitulasi skala Likert terhadap kelima variabel tersebut ditunjukkan pada Tabel 3 .

Tabel 3. Rekapitulasi Skor Skala likert Menurut Responden dan Variabel di Kota Palangka Raya Tahun 2011

\begin{tabular}{cccccc}
\hline $\begin{array}{c}\text { Nomor } \\
\text { Responden }\end{array}$ & $\begin{array}{c}\text { Sarana } \\
\text { Persampahan } \\
(\mathrm{X} 1)\end{array}$ & $\begin{array}{c}\text { Prasarana } \\
\text { Persampahan } \\
(\mathrm{X} 2)\end{array}$ & $\begin{array}{c}\text { Dukungan } \\
\text { Pembiayaan } \\
(\mathrm{X} 3)\end{array}$ & $\begin{array}{c}\text { Timbulan } \\
\text { Sampah } \\
(\mathrm{X} 4)\end{array}$ & $\begin{array}{c}\text { Regulasi } \\
(\mathrm{X} 5)\end{array}$ \\
\hline 1 & 19 & 12 & 17 & 14 & 13 \\
2 & 18 & 13 & 17 & 13 & 13 \\
3 & 18 & 14 & 17 & 13 & 13 \\
4 & 19 & 15 & 15 & 12 & 13 \\
5 & 19 & 11 & 16 & 12 & 12 \\
6 & 22 & 13 & 16 & 12 & 15 \\
7 & 18 & 12 & 16 & 11 & 12 \\
8 & 22 & 15 & 18 & 13 & 15 \\
9 & 18 & 12 & 16 & 11 & 13 \\
10 & 20 & 12 & 16 & 11 & 12 \\
11 & 20 & 11 & 16 & 11 & 14 \\
12 & 24 & 12 & 16 & 11 & 12 \\
\hline
\end{tabular}




\begin{tabular}{cccccc}
\hline 13 & 18 & 13 & 16 & 12 & 14 \\
14 & 20 & 12 & 17 & 12 & 12 \\
15 & 20 & 13 & 18 & 11 & 14 \\
16 & 24 & 11 & 16 & 10 & 14 \\
17 & 23 & 12 & 16 & 11 & 14 \\
18 & 19 & 12 & 16 & 11 & 12 \\
19 & 18 & 13 & 18 & 9 & 13 \\
20 & 18 & 13 & 18 & 9 & 14 \\
21 & 18 & 13 & 18 & 9 & 11 \\
22 & 18 & 13 & 18 & 9 & 14 \\
23 & 18 & 13 & 18 & 9 & 14 \\
24 & 20 & 12 & 17 & 12 & 11 \\
25 & 21 & 13 & 16 & 12 & 13 \\
26 & 18 & 15 & 16 & 12 & 14 \\
27 & 22 & 14 & 17 & 10 & 11 \\
28 & 18 & 12 & 17 & 9 & 10 \\
29 & 18 & 12 & 16 & 11 & 14 \\
30 & 18 & 13 & 18 & 9 & 14 \\
Jumlah & 586 & 381 & 502 & 331 & 390 \\
\hline Sum: Datapris
\end{tabular}

Sumber: Data primer yang diolah, 2021

Berdasarkan nilai tertinggi, jumlah butir pernyataan, dan jumlah responden, dapat ditentukan skor ideal untuk masing-masing variabel, seperti ditunjukkan pada Tabel 4.

Tabel 4. Skor Ideal Variabel Penilaian Kinerja Pengelolaan Sampah berdasarkan Nilai Tertinggi, Jumlah Butir Pernyataan dan Jumlah Responden di Kota Palangka Raya Tahun 2021

\begin{tabular}{lcccc}
\hline \multicolumn{1}{c}{ Variabel } & Nilai tertinggi & Butir & Responden & Score ideal \\
\hline Sarana Persampahan & 4 & 6 & 30 & 720 \\
Prasana Persampahan & 4 & 6 & 30 & 720 \\
Dukungan Pembiayaan & 4 & 6 & 30 & 720 \\
Timbulan Sampah & 4 & 4 & 30 & 480 \\
Regulasi & 4 & 5 & 30 & 600 \\
\hline
\end{tabular}

Sumber: Data primer yang diolah, 2021

Selanjutnya dilakukan perhitungan keberhasilan dan capaian pengelolaan sampah berdasarkan skor ideal pada setiap variabel, dengan persentase dan prioritas seperti pada Tabel 5.

Tabel 5. Hasil Penilaian dan Prioritas Kinerja Pengelolaan Sampah di Kota Palangka Raya Tahun 2021

\begin{tabular}{lccc}
\hline \multicolumn{1}{c}{ Variabel } & Hasil perhitungan & Persentase & Prioritas \\
\hline Sarana Persampahan & 0.8139 & $81 \%$ & 1 \\
Prasana Persampahan & 0.5292 & $53 \%$ & 5 \\
Dukungan Pembiayaan & 0.6972 & $70 \%$ & 2 \\
Timbulan Sampah & 0.6896 & $69 \%$ & 3 \\
Regulasi & 0.6500 & $65 \%$ & 4 \\
\hline
\end{tabular}

Sumber: Data primer yang diolah, 2021

Berdasarkan Tabel 5, tampak bahwa prioritas pertama dalam pengelolaan persampahan adalah sarana persampahan (81\%), diikuti oleh dukungan pembiayaan $(70 \%)$ sebagai prioritas kedua, Timbulan Sampah (69\%) sebagai prioritas ketiga, Regulasi (65\%) sebagai prioritas keempat, dan Prasarana Persampahan (53\%) sebagai prioritas kelima. 
Sarana persampahan sebagaimana dijelaskan pada Peraturan menteri pekerjaan umum Nomor 03/PRT/M/2013 adalah peralatan yang dapat dipergunakan dalam penanganan sampah. Peralatan berdasarkan penelitian ini berupa peralatan dan perlengkapan pengangkutan sampah baik skala lingkungan berupa kendaraan roda tiga/gerobak sampah maupun truck penangkut sampah. Kondisi sarana persampahan di Kota Palangka Raya tidak sebanding dengan jumlah yang tersedia terhadap luas kawasan layanan pengangkutan sampahJumlah sarana peralatan pengangkutan yang kurang dalam hal kuantitas menyebabkan kinerja penangkutan sampah dari aspek pelaksanaan perlu dilakukan peningkatan yang berakibat dilakukannya penambahan ritasi atau waktu penangkutan yang tentunya berimbas kepada biaya operasional perawatan semakin tinggi, dengan demikian keberadaan kendaraan truck sampah yang melayani skala kawasan dan kendaraan gerobak sampah yang melayani daerah pelayanan skala lingkungan berdasarkan data masih sangat kurang dimana pada dasarnya sesuai dengan cakupan wilayah yang terbagi dalam jalur pengangkutan sampah melalui depo yang terletak pada 3 lokasi.

Variabel Pembiayaan merupakan prioritas kedua dalam pengelolaan sampah di Kota Palangka Raya. Sebagai salah satu isu strategis dalam mengelola persampahan adalah dukungan pembiayaan yang masih rendah sehingga terkesan seadanya serta berpengaruh terhadap kebersihan lingkungan dan kesehatan masyarakat. Dukungan pembiayaan dalam operasional sampah dimulai dari sumber sampah/penyapuan, pengumpulan, transfer dan pengangkutan dan pembuangan akhir. Alokasi ABPD untuk biaya operasional penanganan dan pengelolaan sampah berdasarkan indikator penelitian masih sangat rendah, hal ini disebabkan postur anggaran APBD masih menguras anggaran dari sisi prioritas pembangunan infrastruktur, adanya persepsi dalam mengambil keputusan adalah upaya-upaya yang harus disamakan demi membangun pengelolaan persampahan agar memiliki perhatian yang seimbang. Peningkatan pemulihan biaya pengelolaan persampahan dapat melalui pendanaan dari masyarakat dengan menerapkan peran serta masyarakat dalam dukungan pembiayaan persampahan. Dukungan pembiayaan dalam menunjang kinerja pengelolaan sampah di Kota Palangka Raya Tahun 2021 mengalami peningkatan yang signifikan dibandingkan Tahun 2020, yaitu mencapai Rp. 4.050.015.649,00 atau meningkat $143 \%$ dbandingkan anggaran Tahun 2020. Jika diuraikan lebih lanjut, pendanaan yang disediakan melaui APBD tersebut lebih banyak digunakan untuk pembiayaan prasarana, yaitu Rp. 2.037.448.285,00 atau 71,8 \% dari anggaran Pengelolaan Sampah Tahun 2020, dan Rp. 2.673.500.00,00 atau 38,8 \% dari anggaran Pengelolaan Sampah Tahun 2021 (Dinas Lingkungan Hidup Kota Palangka Raya, 2021).

Prioritas ketiga dalam pengelolaan sampah adalah Timbulan Sampah. Timbulan sampah di Kota Palangka Raya berasal dari berbagai sumber, yaitu: sampah domestik, sampah pasar, sampah rumah makan, sampah hotel, sampah fasilitas pendidikan, dan sampah perkantoran. Sampah terbanyak berasal dari sampah domestik, diikuti oleh sampah pasar pada urutan kedua, dan sampah rumah makan pada urutan ketiga, sedangkan sampah terkecil adalah yang berasal dari sampah pendidikan. Jumlah tmbulan sampah menurut sumber sampah dapat dilihat pada Gambar 1. Kebutuhan sarana dan prasarana ditentukan pula oleh kondisi timbulan sampah yang ada. Mengacu kondisi eksisting dimana sarana persampahan yang menjadi prioritas penanganan kinerja yang pertama berdasarkan hasil pengolahan data kuisioner, belum seimbang dengan jumlah timbulan sampah berdasarkan data diatas, sehingga menjadi prioritas ketiga dalam peningkatan kinerja pengelolaan sampah yang harus ditangani, dengan demikian berdasarkan hasil penelitian terhadap 30 responden tersebut penanganan timbulan sampah menjadi prioritas ketiga sesuai dengan data timbulan sampah yang ada. 


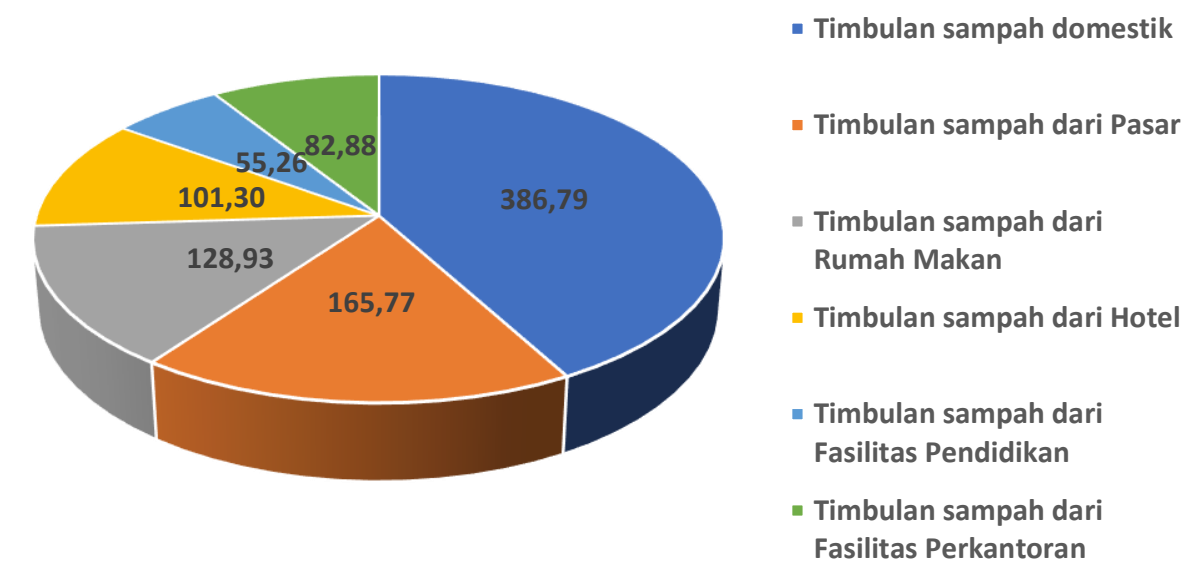

Gambar 1. Timbulan Sampah (m3 / hari) di Kota Palangka Raya menurut Sumber Sampah

Regulasi menjadi prioritas keempat yang perlu ditangani. Regulasi yang ada terkait dengan pengelolaan sampah secara lokal hanya dinaungi oleh Peraturan Daerah Kota Palangka Raya Nomor 1 Tahun 2017 tentang Pengelolaan Sampah dan Kebersihan dan Peraturan Walikota Palangka Raya Nomor 43 Tahun 2017 tentang Peraturan pelaksanaan Peraturan Daerah Kota Palangka Raya Nomor 1 Tahun 2017 tentang Pembuangan sampah dan Kebersihan dan Lingkungan, hal ini dianggap belum cukup, karena regulasi juga diperlukan sebagai pengaturan dalam operasional detail yakni Standar Operasional Prosedur (SOP) terkait pengelolaan sampah baik SOP Pengangkutan, SOP Pemeliharaan prasarana dan sarana, SOP Waktu Kerja, SOP Personil, SOP Evaluasi dan Monitoring serta SOP lainnya yang terkait. Selain SOP, Regulasi lainnya perlu disusun kembali mengacu kepada Norma Standar Prosedur dan Kriteria (NSPK) Pengelolaan sampah, dimana dalam N.S.P.K. yang disusun juga mengacu kepada Tujuan Pembangunan Berkelanjutan (SDGs) serta RPJMD 2019-2024. Konsekwensi dari regulasi yang dibangun tersebut tentunya menjadi payung dalam penganggaran APBD juga usulan pendanaan diluar APBD bisa pihak ketiga berupa CSR maupun pembiayaan oleh APBN. Dengan demikian aspek regulasi saat ini perlu untuk di lengkapi dengan regulasi yang bersifat Konseptual dan operasional.

Selanjutnya variabel Prasarana Persampahan menjadi prioritas kelima dalam penilaian kinerja pengelolaan sampah. Prasarana persampahan di Kota Palangka Raya dinilai masih mampu memenuhi kebutuhan pengelolaan persampahan. Namun demikian, masih dibutuhkan peningkatan penyediaan prasarana persampahan, anatara lain: peningkatan jumlah Depo Besar pada beberapa lokasi, pengembangan pengelolaan sampah di TPA menjadi sanitary landfill, peningkatan fungsi bank sampah dan pengembangan unit sampah pada tiap RT, dan pengembangan tong komposter dan rumah kompos.

\section{c. Pola Penanganan dan Komitmen Pemerintah Kota Palangka Raya}

Dalam RPJMD 2018-2023 terhadap penganggaran pertahun dalam DPA SKPD Lingkungan Hidup Kota Palangka Raya perlu konsistensi berdasarkan indicator dalam RPJMD. Dimana dalam RPJMD 2018-2023, pada tahun 2020 target capaian Persentase (\%) sampah yang tertangani sebesar $90 \%$ dengan Pagu anggaran Rp. 9,593,500,542,- dan tahun 2021 target $90 \%$ dengan pagu Rp. 9,593,500,542,-. Tetapi didalam realisasinya pada tahun 2020 hanya sebesar $\pm 25 \%$ dengan pagu Rp. 2.838.424.035,dan tahun 2021 Realisasi nya $\pm 60 \%$ dengan pagu Rp. Rp. 6.888.439.688,-, dan berdasarkan struktur APBD Kota Palangka Raya alokasi anggaran tahun 2021, yang fokus kepada penanganan sampah secara langsung hanya sebesar Rp. 2.673.500.000,-. Dengan demikian, Konsistensi terhadap RPJMD 2013-2023 harus disesuaikan sehingga target kinerja pengelolaan sampah dalam kurun waktu 20182023 dapat tercapai. 


\section{d. Kebijakan dan Rencana Berdasarkan Rencana Aksi Daerah Air Minum dan Peyehatan Lingkungan (RAD-AMPL) Kota Palangka Raya Tahun 2019-2024.}

Rencana indikasi program dan kebijakan pemerintah Kota Palangka Raya, bisa dikatakan cukup baik pada tataran konsep tetapi konsistensi dalam dukungan pendanaan pengelolaan sampah harus tetap terpelihara dan berkomitmen untuk penerapannya dalam anggaran tahunan APBD. Berdasarkan RPJMD 2018-2023 dan RAD-AMPL 2019-2023, telah terlihat komitmen yang dilakukan dalam dokumen sebagai rujukan dalam pelaksanaan pembangunan khususnya pengelolaan persampahan sudah cukup baik, hanya saja perlu komitmen kepala SOPD terkait bersama Pimpinan Daerah dan DPRD dalam merumuskan tindak lanjut berbasis kinerja dan anggaran setiap tahunnya untuk meningkatkan kinerja pengelolaan sampah di Kota Palangka Raya.

\section{Kesimpulan dan Saran}

\section{a. Kesimpulan}

1. Prioritas pertama pengelolaan sampah di Kota Palangka Raya adalah Sarana Persampahan, dikuti oleh prioritas kedua adalah dukungan pembiayaan, prioritas ketiga adalah Timbulan Sampah, prioritas keempat adalah Regulasi, dan prioritas kelima adalah Prasarana persampahan.

2. Kondisi sarana pengelolaan persampahan seperti keberadaan kendaraan truck sampah yang melayani skala kawasan dan kendaraan gerobak sampah yang melayani daerah pelayanan skala lingkungan berdasarkan data masih sangat kurang dimana pada dasarnya sesuai dengan cakupan wilayah yang terbagi dalam jalur pengangkutan sampah melalui depo yang terletak pada 3 lokasi.

3. Pembiayaan pengelolaan sampah yang disediakan pemerintah Kota Palangka Raya meningkat sangat signifikan pada Tahun 2021 dibandingkan Tahun 2020, namun proporsi terbesar digunakan untuk prasarana persampahan.

4. Jumlah timbulan sampah di Kota Palangka Raya belum seimbang dengan kinerja pengelolaan persampahan, sehingga peningkatan kinerja harus dilakukan.

5. Berdasarkan hasil penelitian diperoleh bahwa regulasi pengelolaan sampah secara lokal hanya dinaungi oleh Peraturan Daerah Kota Palangka Raya Nomor 1 Tahun 2017 tentang Pengelolaan Sampah dan Kebersihan dan Peraturan Walikota Palangka Raya Nomor 43 Tahun 2017 tentang Peraturan pelaksanaan Peraturan Daerah Kota Palangka Raya Nomor 1 Tahun 2017 tentang Pembuangan sampah dan Kebersihan dan Lingkungan, hal ini dianggap belum cukup.

6. Prasarana persampahan di Kota Palangka Raya dinilai masih mampu memenuhi kebutuhan pengelolaan persampahan hanya perlu ditingkat dari segi kuantitas.

\section{b. Saran}

1. Penambahan sarana pengelolaan persampahan seperti kendaraan truck sampah yang melayani skala kawasan dan kendaraan gerobak sampah yang melayani daerah pelayanan skala lingkungan.

2. Peningkatan pemulihan biaya pengelolaan persampahan dapat melalui pendanaan dari masyarakat dengan menerapkan peran serta masyarakat dalam dukungan pembiayaan persampahan.

3. Dalam hal penanganan timbulan sampah perlu peningkatan jumlah dan jam operasional prasarana persampahan dalam hal pengangkutan sampah agar mampu seimbang dengan timbulan sampah yang terjadi di Kota Palangka Raya.

4. Aspek regulasi perlu di lengkapi dengan regulasi yang bersifat Konseptual dan operasional. Konsekwensi dari regulasi yang dibangun tentunya menjadi payung dalam penganggaran APBD juga usulan pendanaan diluar APBD.

5. Peningkatan kuantitas Prasarana persampahan di Kota Palangka Raya dapat menambah nilai kemampuan pengelolaan persampahan.

6. Peningkatan kinerja pada pengelolaan sampah terhadap kelima aspek seperti Sarana Persampahan, Dukungan Pembiayaan, Timbulan Sampah, Regulasi dan Prasarana Persampahan menjadi kunci utama sehingga perlu di riview setiap tahunnya agar menjaga kelangsungan lingkungan hidup dan sumberdaya manusia di Kota Palangka Raya. 
7. Diperlukan sinergitas yang lebih kuat antara Pemerintah dan masyarakat dalam pengelolaan persampahan seperti lebih gencar dan intensif terhadap peran serta masyarakat melalui program 3R berbasis peran serta masyarakat agar lebih mampu menjangkau hal terkecil dalam menangani pengelolaan sampah di Kota Palangka Raya demi mencapai Kota Palangka Raya yang maju, rukun dan sejahtera agar menjadi lingkungan yang cerdas (smart environment).

\section{Daftar Pustaka}

Badan Pusat Statistik Kota Palangka Raya. 2019. Palangka Raya Dalam Angka Tahun 2019. Palangka Raya: Badan Pusat Statistik.

Dinas Lingkungan Hidup Kota Palangka Raya. 2019.

Hartanto, H. 2006. Keluarga Berencana dan Kontrasepsi. Jakarta: Pustaka Sinar Harapan.

Kuncoro. Mudrajad. 2009. Metode Riset untuk Bisnis dan Ekonomi. Edisi 3. Jakarta: Erlangga.

Moersid. 2004. Konsep National Action Plan Pengelolaan Sampah dalam rangka Millenium Development Goals. Semarang: Jurnal.

Nuryani. 2003. Jurnal Ilmu Tanah dan Lingkungan. Yogyakarta: UGM.

Slamet, M. 2000. Memantapkan Posisi dan Meningkatkan Peran Penyuluhan Pembangunan Dalam Pembangunan. Jakarta: Salemba Empat.

Undang - Undang Republik Indonesia Nomor 18 Tahun 2008 Tentang Pengelolaan Sampah. 